\title{
PALEOENVIRONMENTAL SIGNIFICANCE OF STROMATOLITES IN THE AMERICUS LIMESTONE MEMBER (LOWER PERMIAN, MIDCONTINENT, USA)
}

\author{
Larry E. Denver $\mathrm{II}^{1}$ and Roger L. Kaesler \\ Department of Geology, Paleontological Institute, and Museum of Invertebrate Paleontology \\ The University of Kansas, Lawrence, Kansas 66045-2911
}

\begin{abstract}
Low-relief stromatolites in the lower part of the Americus Limestone Member of the Foraker Limestone (Permian, Wolfcampian) of northeastern Kansas occur with five distinct morphologies. These stromatolites record Early Permian depositional environments that ranged from supratidal to open marine and include a lagoon and an incipient carbonate shoal. Stromatolites with pod morphology are indicative of supratidal and upper-intertidal deposition. Pustular and laminoid stromatolites are characteristic of an ephemeral lagoon. Smooth and mottled stromatolites indicate, respectively, deposition on the carbonate shoal (lower-intertidal zone) and in the subtidal, open-marine environment. These stromatolites formed in response to physical parameters of the environment, including water depth, wave energy, frequency of exposure, degree of desiccation, and rate of sedimentation. An environmental-process grid for low-relief stromatolites plots each morphological type with respect to relative level of environmental energy and the degree of desiccation. The information in the grid can be applied to similar, low-relief stromatolites in other cyclothems of the Midcontinent, including those found in subsurface cores.
\end{abstract}

\section{INTRODUCTION}

Low-relief stromatolites with five distinct morphologies can be distinguished in the lowermost Americus Limestone Member in northeastern Kansas: smooth, pustular, laminoid, mottled, and podlike. The purpose of this study is to relate these morphologies to the depositional environments of the Americus and to produce an environmental-process grid that shows the relationships graphically. In a detailed petrological study, Fisher (1980) recognized four nearshore environmental settings: tidal flat, lagoon, carbonate shoal, and open marine. The boundaries between these environments (Fig. 1), although not sharply defined, correspond roughly with the boundaries between areas dominated by deposits of the five kinds of stromatolites.
The Americus lies at the base of the Council Grove Group and is a member of the Foraker Limestone (Fig. 2). It unconformably overlies the Hamlin Shale Member of the Janesville Shale (Admire Group) and consists predominantly of limestone with interbedded shale. On average the Americus is about a meter thick in the study area. It ranges in thickness from less than $0.5 \mathrm{~m}$ near the Kansas-Nebraska border to about $6 \mathrm{~m}$ in southern Kansas (Fisher, 1980). The stromatolites studied here lie in the basal $10 \mathrm{~cm}$ of the Americus just above the unconformity.

Many geologists and paleontologists have studied the Americus, including Elias (1937, 1962, 1964), Moore (1959, 1964), Mudge and Yochelson (1962), Garber (1962), McCrone (1963, 1964), Imbrie et al. (1964), Harbaugh and Demirmen (1964), Peterson and Kaesler (1980), Sporleder $(1987,1991)$, and Kaesler et al. (1990). Fisher's

${ }^{1}$ Present address: STRATAMODEL, 7500 San Felipe, Suite 500, Houston, Texas 77063. 


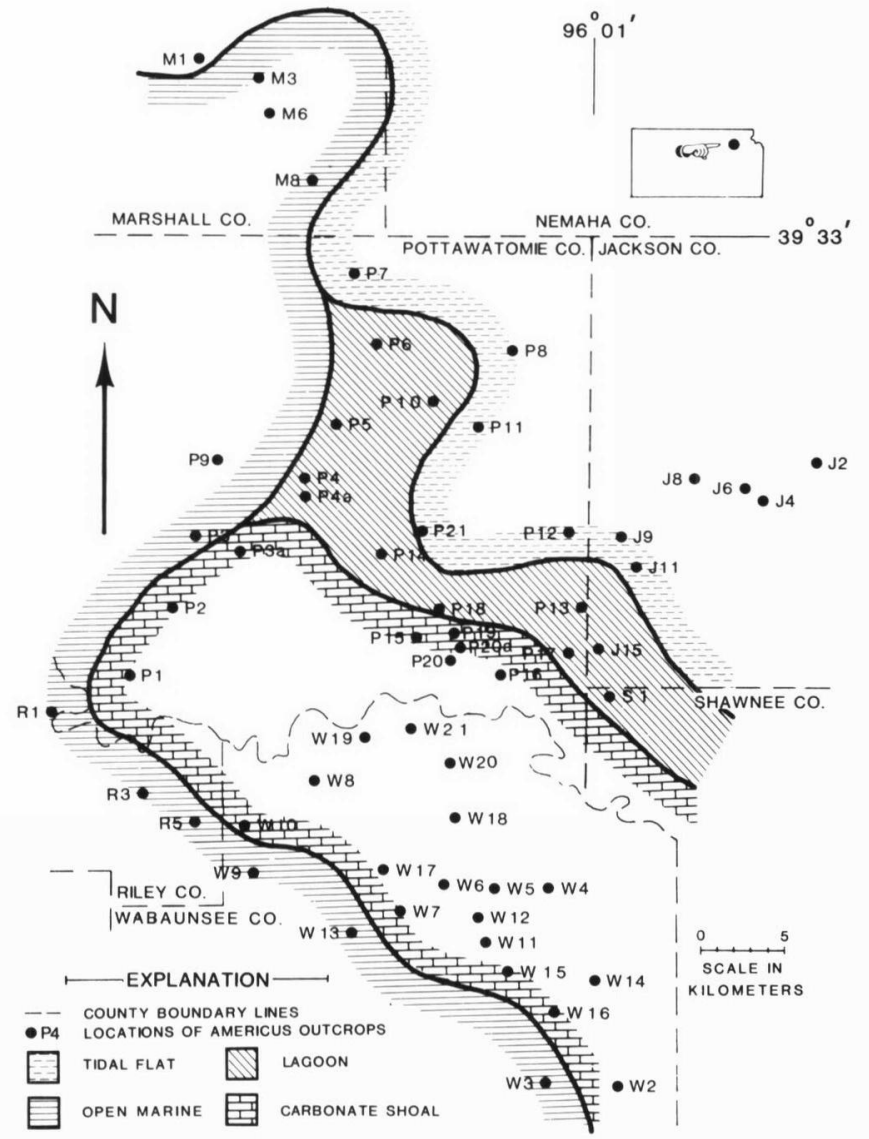

Fig. 1. Map of sampled localities superimposed on paleoenvironmental interpretation of the lower Americus Limestone Member (after Fisher, 1980).

(1980) research, however, is the most recent and comprehensive on the upper part of the Hamlin and on the Americus in the area from which we studied stromatolites. We have based much of our study on his careful stratigraphical and paleoenvironmental analysis. Fisher investigated the Nemaha anticline's effect on depositional environments and concluded that late tectonic uplift of the anticline affected deposition of the Americus but not the uppermost Hamlin. His determination of paleoenvironments (Fig. 3) was based on observations that included the entire lower Americus. The basal stromatolites, however, formed only during the initial stages of Americus deposition and were not influenced by later environments of deposition.

\section{STROMATOLITES AND ENVIRONMENTS}

Although stromatolites occur in many environments, most of those in Phanerozoic rocks formed in such nearshore, shallow-water environments as those of Shark Bay in western Australia. The stromatolites of Shark Bay are spectacular and morphologically variable (Logan, 1961, 1974; Logan et al., 1964, 1974; Davies, 1970; Hoffman, 1976; and Playford and Cockbain, 1976). Their study has provided information for environmental-process grids
(Hoffman, 1976, p. 265, fig. 4), which are useful aids for environmental interpretation because they relate the morphology of stromatolites to the degree of desiccation, rate of sedimentation, or energy level of the environment.

The environmental-process grids developed from studies of Shark Bay, however, are not entirely applicable to such low-relief structures as occur in the Americus, for which a new environmental-process grid is presented below. As Hoffman in describing the Hamelin Pool of Shark Bay wrote (1976, p. 271): "Although Hamelin Pool contains the most diverse assemblage of modern stromatolites, many ancient stromatolites doubtless grew in environments not represented there. This is particularly true for sublittoral settings of low environmental stress, where the conclusions regarding stromatolite morphogenesis in shoreline environments ... may not be applicable."

\section{DESCRIPTION AND INTERPRETATION}

Smooth stromatolites.-Stromatolites with smooth morphology are confined roughly to the area of the carbonate shoal (Figs. 4 and 5). They vary from flat to undulating with some development of laterally linked hemispheroids and small stacked hemispheroids (Fig. 6) (classification of Logan et al., 1964). The thickness of these stromatolites

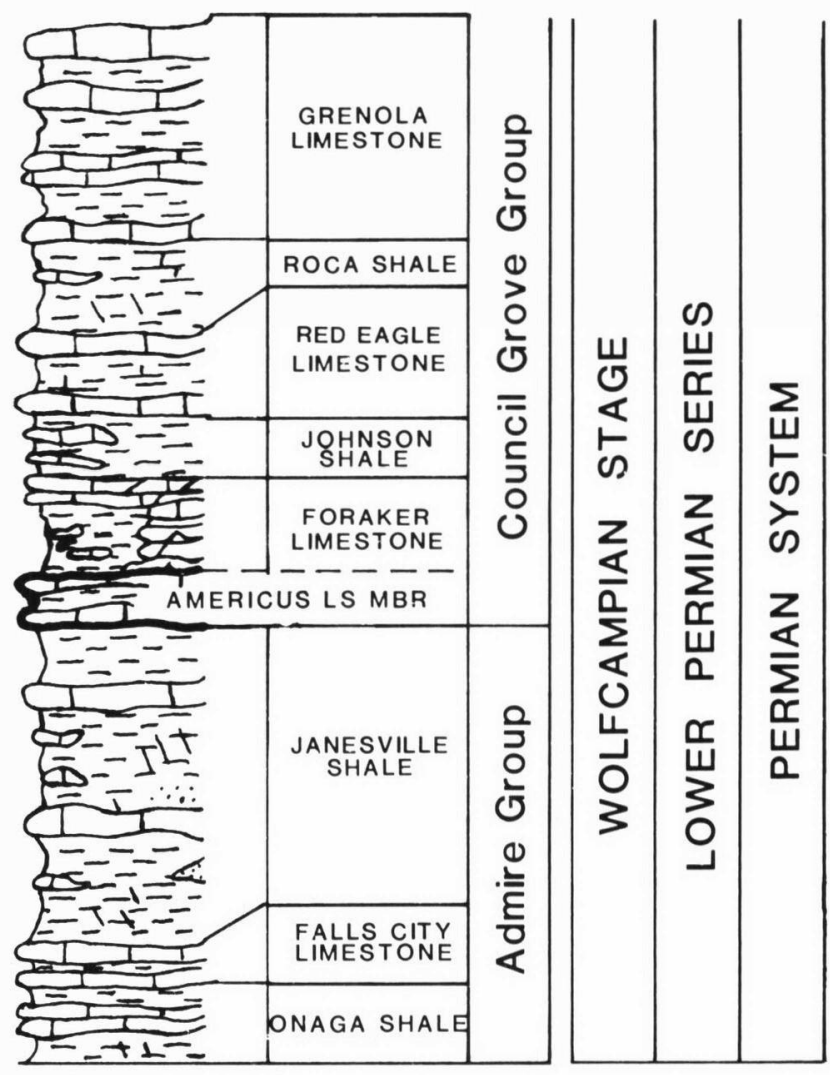

Fig. 2. Stratigraphic nomenclature of part of the Lower Permian of the Midcontinent (after Zeller, 1968). 


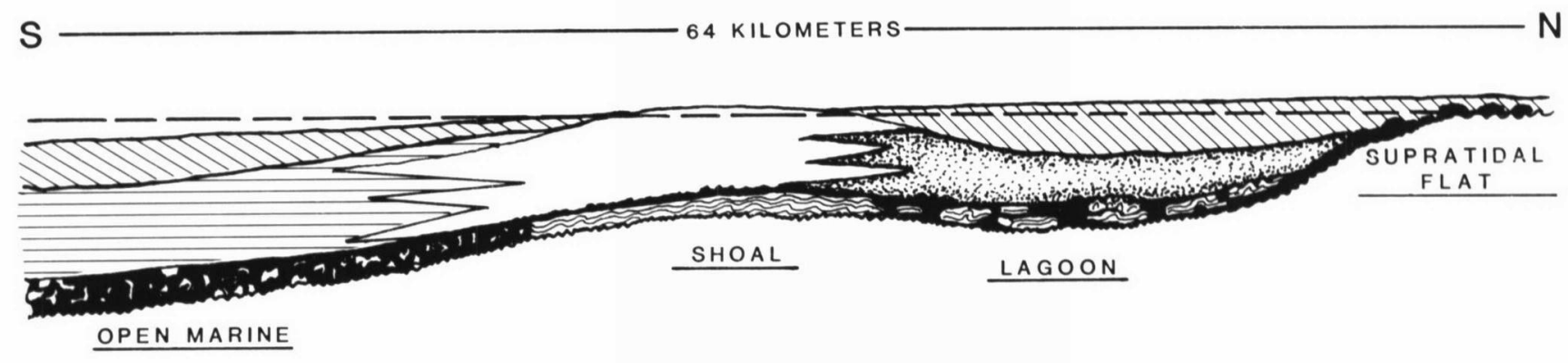

OPEN MARINE

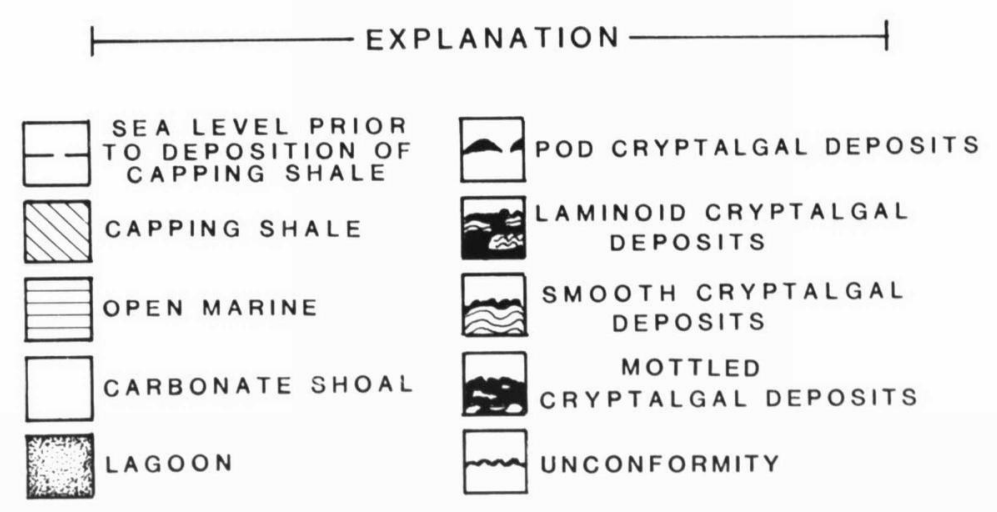

Fig. 3. Schematic north-south cross section of the lower Americus Limestone Member showing distribution of paleoenvironments and morphology of stromatolites (after Fisher, 1980).

averages about $4 \mathrm{~cm}$ across the study area, and the overlying and underlying deposits consist of ostracode and foraminifer packstones (classification of Dunham, 1962).

The smooth stromatolites and closely associated facies comprise three distinctly different and laterally persistent layers. The basal layer contains abundant Spirorbis worm tubes coated by a combination of algae, probably Girvanella, and encrusting foraminifera (Fig. 7,1). This layer is quite thin, irregular, and in many areas poorly preserved. Overlying the basal layer is a peloidal, flat to wavy-laminated and laminoid zone that has desiccation cracks and forms most of the deposit. The zone consists of laminoid pelmicrites, laminated and rippled pelsparites, and thin, discontinuous peloidal grainstones in layers up to $3 \mathrm{~mm}$ thick. These peloidal grainstones overlie domal heads and pinch out between them (Fig. 7,2). The pelmicrites are muddy and have vermiform fabric (Pratt, 1982) that is truncated by thin, horizontal beds of micrite (Fig. 7,1). The pelsparites are characterized by minor exposure surfaces and micritized grains of fine-silt to granule size surrounded by fibrous, isopachous cements. Micritic beds occur at the top of the pelsparite. In places desiccation cracks are filled with sediment, but they typically contain only spar. The thin, upper layer is dominated by a combination of filamentous algae and encrusting foraminifera that grew in small, stacked hemispheroids and digitate columns (Fig. 7,3). The thickest portions formed over preexisting highs in the underlying peloidal stromatolite layer, whereas either no upper stromatolitic layer or a much reduced layer occurs above the low points in the underlying deposit. In most areas this layer has been disrupted by browsing organisms and is separated from the peloidal stromatolite by a thin, iron-stained layer. Detrital quartz and bioclasts accumulated between the small, digitate columns.

The smooth stromatolites, which bear a striking resemblance to smooth mats in Shark Bay (Logan et al., 1974), were almost certainly deposited in the intertidal zone. The fine, horizontal fenestrae (Logan, 1974), minor exposure surfaces, rippled pelsparites (Davies, 1970), restricted fossil assemblage immediately below the stromatolite, and alternating peloidal and alga-rich laminations (Ginsburg et al., 1954; Ginsburg, 1955; Logan, 1961, 1974; Monty, 1967; Park, 1976) all strongly suggest deposition in a lowerto middle-intertidal setting. The limited bioturbation (Gebelein, 1969, 1976) and the high ratio of detrital sedimentary grains to algally bound material (see Davies, 1970) also indicate deposition in the lower intertidal zone. Evidence that desiccation occurred primarily during deposition of the peloidal layer is provided by the small, sparfilled, vertical cracks and horizontal fenestrae. Worm tubes directly below the peloidal layer may also suggest subaerial exposure and the worms' attempt to escape exposure (Gerdes et al., 1985). Thicker layers of sediment resulted from increased influx of peloids and skeletal fragments, presumably during unusually high tides or as a result of prolonged onshore winds. The fact that the sediment is thickest over domal heads and thins toward the lower portions of the deposit suggests that it was not deposited by storms (see Shinn et al., 1969). Slight vertical 


GASTROPODS

Fig. 4. Explanation of paleontological and lithological symbols used in Figures 5, 9, 10, and 11.

variation within the peloidal stromatolites from pelmicrite to pelsparite may indicate variation in tidal currents due to shifting winds.

The morphology of the upper alga- and foraminiferarich layer is quite similar to colloform stromatolites of Shark Bay that form only in subtidal settings (Logan, 1974). The fabric is similar to subtidal capping sequences in Permian mud mounds of the Sacramento Mountains described by Toomey and Babcock (1983). Moreover, in his study of Gladstone Embayment in Shark Bay, Davies (1970) noted an increase in encrusting foraminifera from shore towards sublittoral mounds. There was more browsing of this layer of the Americus than of the peloidal deposit, also suggesting deepening of the water and a trend towards more normal-marine conditions.

Pustular and Laminoid Stromatolites. - These stromatolites and their associated facies are nearly confined to the area of the lagoon (see Fig. 9; see also Fisher, 1980) and are more variable than the smooth type (Fig. 6). The pustular stromatolites (Fig. 7,4) contain Spirorbis worm tubes with algae and encrusting foraminifera underlying a peloidal layer. These are laterally discontinuous and topped by a thin layer of algae and encrusting foraminifera growing in digitate columns or laminoid layers. An iron-stained, quartzrich packstone lies both above and beneath such stromatolites. Laminoid stromatolites are also laterally discontinuous, but they are generally thicker than pustular deposits and contain domal structures and U-shaped peloidal sections (Fig. 7,5). Stromatolites with this morphology are underlain by iron-stained conglomerate and overlain by shale. Whereas the pustular deposits are no thicker than 5 $\mathrm{cm}$, the laminoid structures are as thick as $20 \mathrm{~cm}$ and may incorporate pustular structures.

The fabric of pustular stromatolites is markedly different from that of smooth deposits. Pustular stromatolites are characterized by the presence of large, spar-filled, collapsed, and brecciated pustules and are largely unlaminated. The tops of pustules are filled with ironstained spar, and the bases contain brecciated material with Spirorbis worm tubes, foraminifera-rich sediment, and alga-rich micrite. The roof above the pustules varies from fine peloidal mud to algal and foraminiferal remains with few worm tubes. Desiccation or fracturing developed voids that contain fractured mud shards.

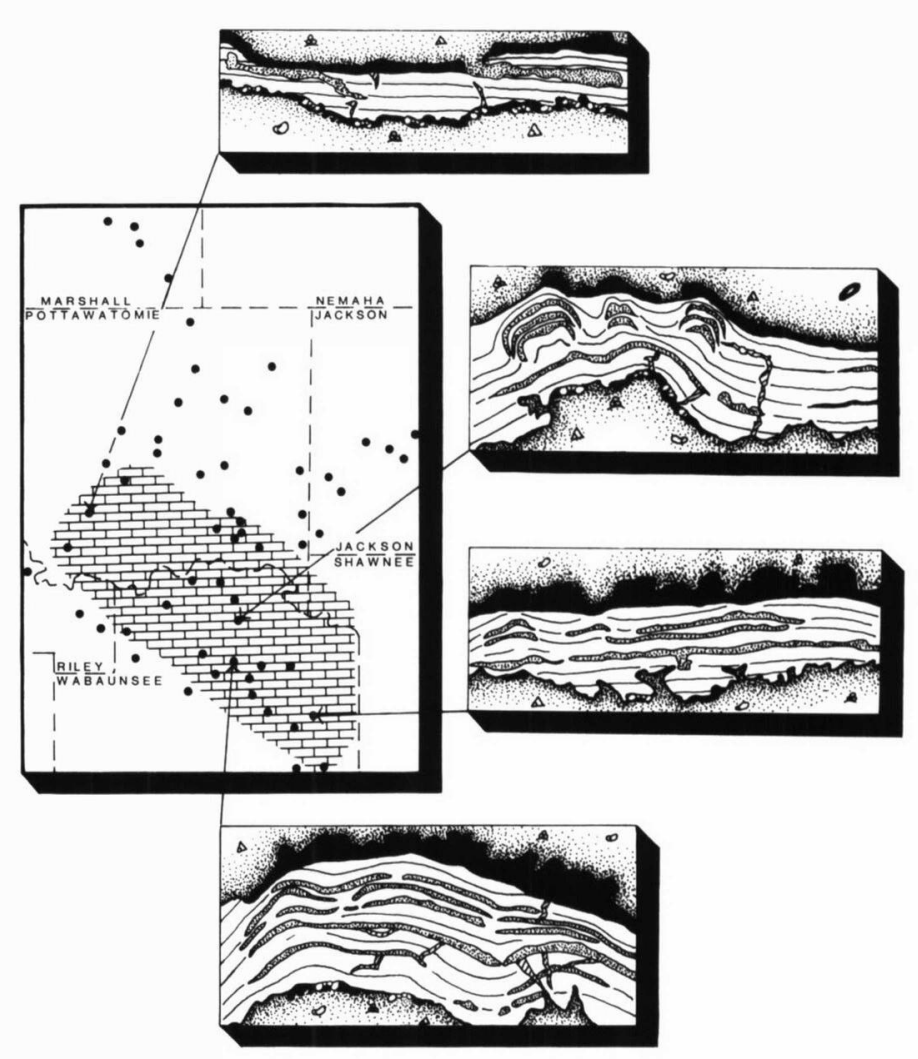

Fig. 5. Localities sampled, extent of the carbonate shoal (block pattern), and drawings of four, typical, smooth stromatolites, $\times 0.4$. See Figure 4 for explanation of symbols. 


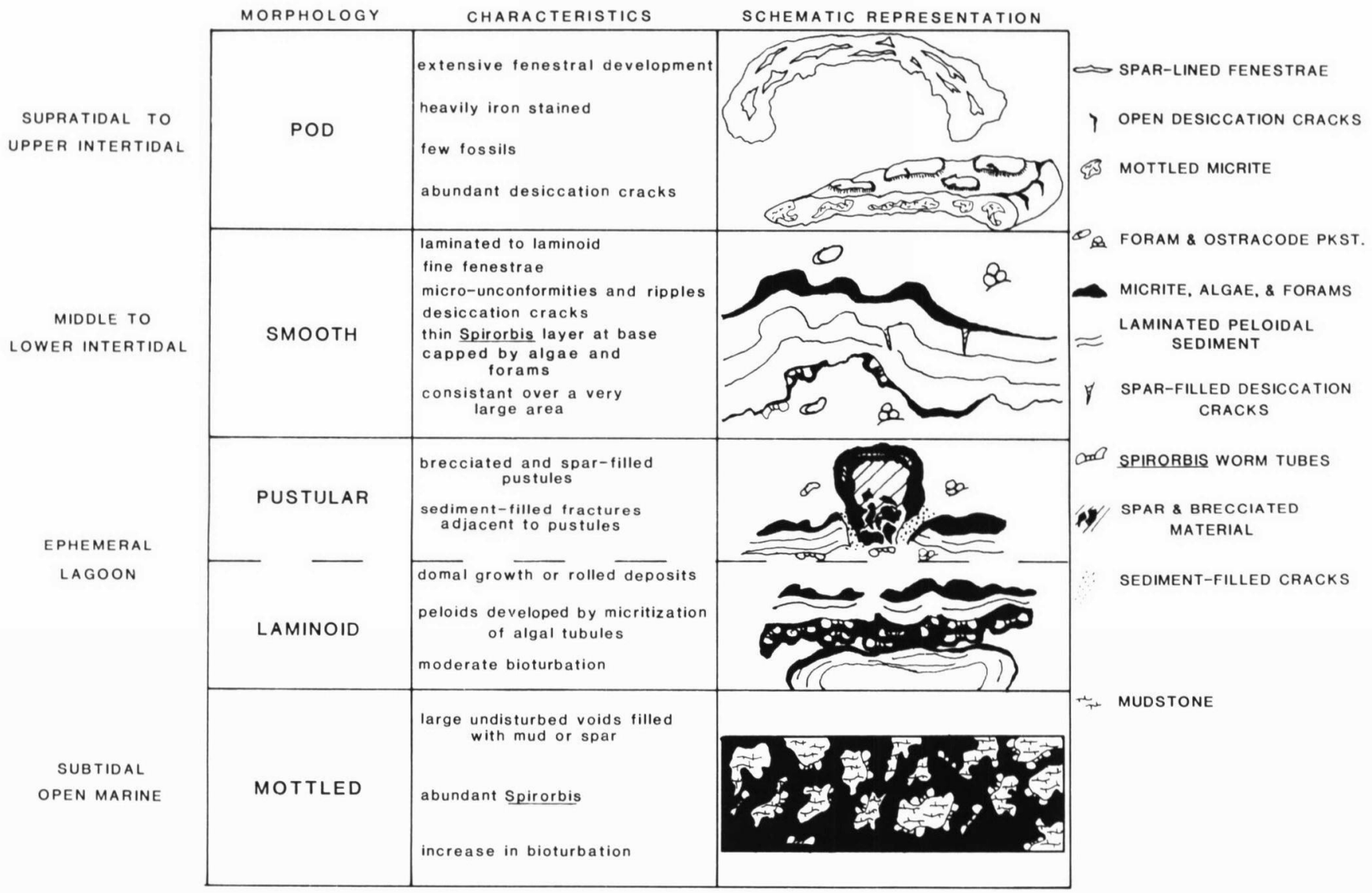

Fig. 6. Morphology and characteristics of stromatolites from four nearshore environments.

Peloidal layers associated with pustular stromatolites are typically dominated by pelmicrite, are laminated to laminoid, and were fractured, desiccated, or both (Fig. $7,6)$. Although some peloids are micritized fossil fragments, much of the peloidal rock appears to contain algal tubules surrounded by micrite. Overlying the peloidal layer is an algal and foraminiferal boundstone that is digitate to laminoid and similar to that in smooth deposits. Exposed pustular surfaces are irregular with small, rounded domes or pustules approximately $2 \mathrm{~cm}$ in diameter and height (Fig. 8,1).

Laminoid stromatolites and associated facies are dominated by Spirorbis and by algal and encrusting-foraminiferal zones that include partially collapsed, centimeter-sized voids filled with sediment or spar (Fig. 8,2). Also included are small, domal heads that grew over sediment or that may have been rolled by currents, as well as contorted layers of fractured pelmicrites (Fig. 7,5). The surfaces of these deposits have desiccation cracks and irregular topography. Outcrops of these stromatolites are oblate and massive.

The general morphology of pustular and laminoid stromatolites suggests that they were deposited in an ephemeral lagoon. The differences in their morphologies may have resulted from subtle variation in topography so that some portions of the lagoon were submerged, while others were briefly emergent or underwent little accretion. The desiccation cracks of the laminoid stromatolites indicate subaerial exposure, whereas the digitate algal and foraminiferal boundstones and Spirorbis worm tubes of the pustular stromatolites are typical of shallow-water, subtidal deposition (Toomey and Babcock, 1983). These stromatolites have a higher ratio of algae to sediment than the smooth stromatolites, characteristic of lagoonal or marsh deposits as was determined from studies in Gladstone Embayment and the Bahamas (Davies, 1970; Hardie and Ginsburg, 1977). The significantly higher number of algal tubules within the peloids indicates in situ production of peloids. The micritization of algal bundles produced both the peloidal and, in places, spongiform fabric and indicates that the peloids are not detrital (see Monty, 1976; Coniglio and James, 1984).

The brecciated sections of the pustular stromatolites are enigmatic. Convoluted mats in Gladstone Embayment have identical morphologies that result from a rise in the water table after periods of subaerial exposure (Davies, 1970 , p. 192, fig. 15a, b). Air forced up through the sediment pushes the mat upward, forming voids beneath it 

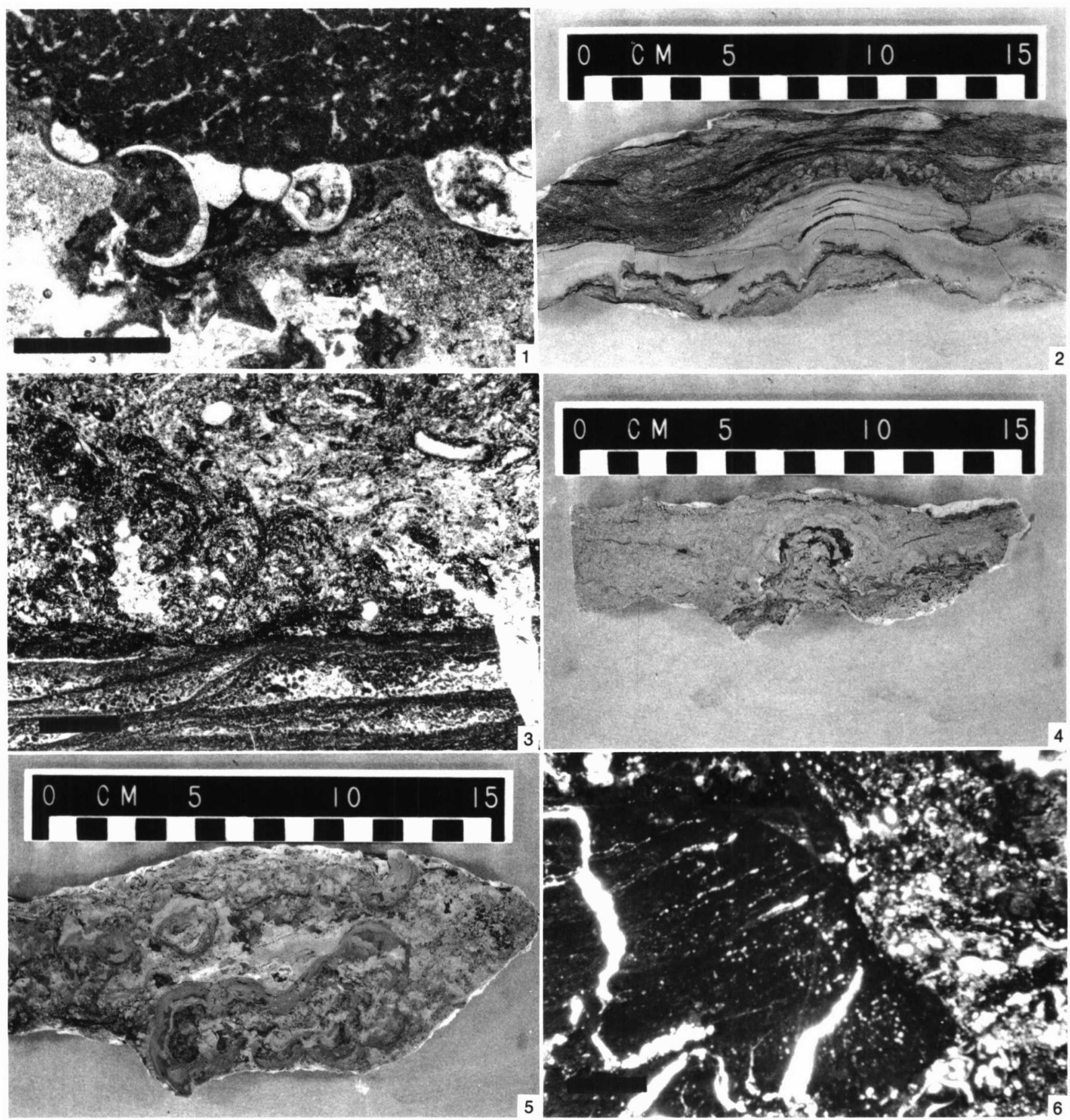

Fig. 7. Stromatolites with smooth, pustular, and laminoid morphologies._- Spirorbisworm tubes, algae (probably Girvanella), and encrusting foraminifera directly below peloidal deposits at locality P2; micrite layers and a vermiform fabric typify the overlying peloidal deposits; bar is $2 \mathrm{~mm}$; photomicrograph, KUMIP no. 214,925.—- Sheet cracks over domes in the peloidal layer; slab, KUMIP no. 214,888. 3. Sample from locality W6 showing digitate heads rich in foraminifera and algae, rippled pelsparite, and a desiccation crack (right); bar is $2 \mathrm{~mm}$; photomicrograph, KUMIP no. 214,923.__ 4. Pustular stromatolite from locality P10; slab, KUMIP no. 214,840.— 5. Laminoid stromatolite showing subtle layering, U-shaped segments, and rolled structures; slab, KUMIP no. 214,788. 6. Pelmicrite zone in pustular stromatolite facies, locality P10, showing fractures or possible desiccation cracks and large, sediment-filled crack to the right; bar is $2 \mathrm{~mm}$; photomicrograph, KUMIP no. 214,926.

(Davies, 1970). This is the most likely modern analog of the brecciated pustular structures, although gas produced by decaying algae may also have been partially responsible. The former interpretation is supported by breccia- tion of the worm-tube-rich layer below the voids as well as vertical orientation of sediment in small plumes beneath some voids. In addition, sediment-filled fractures commonly occur next to the voids where the stromatolites turn sharply 

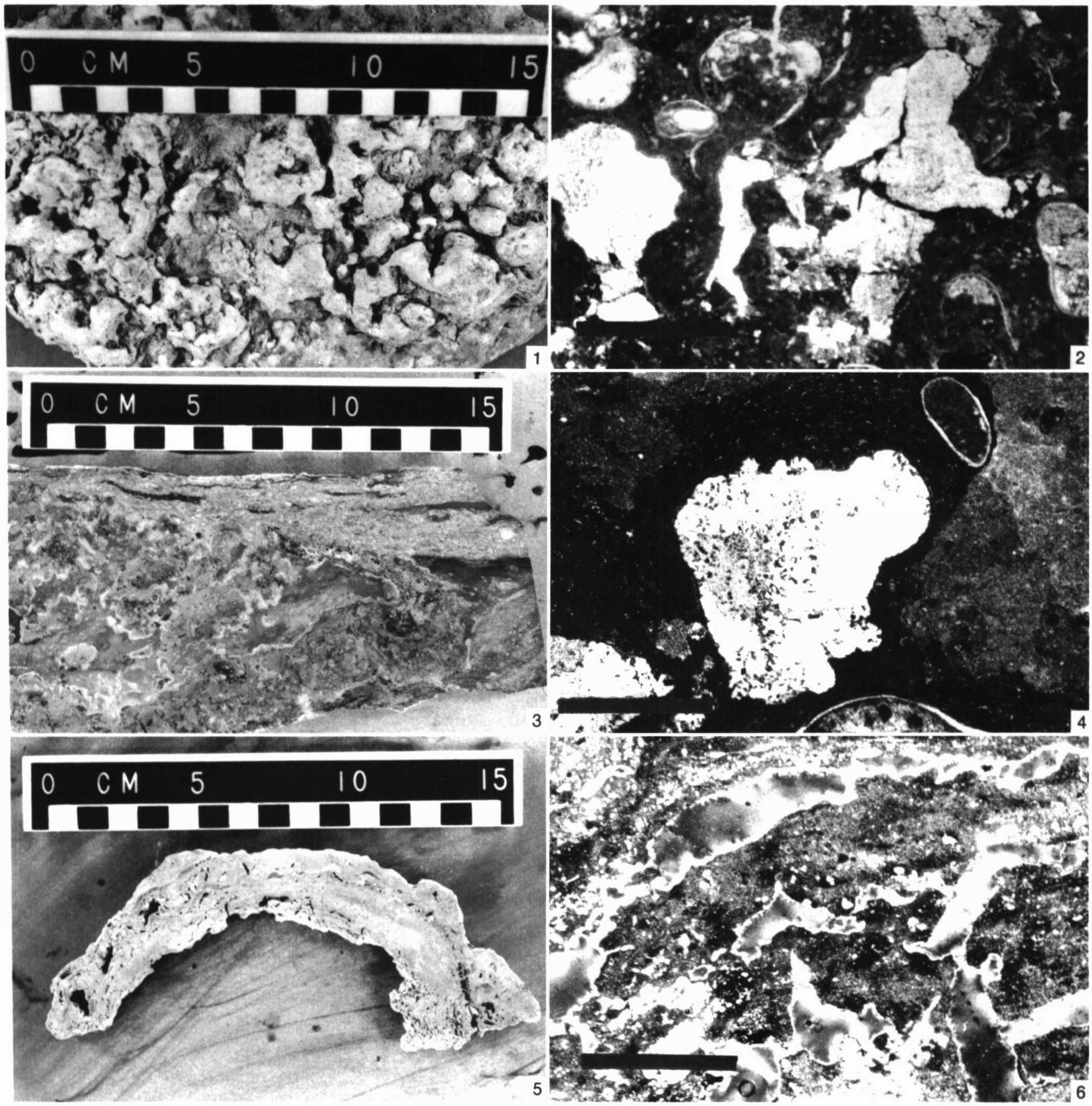

Fig. 8. Stromatolites with pustular, laminoid, mottled, and podlike morphology._- 1 . Surface of pustular stromatolite from locality P6; KUMIP no. 214,968. 2. Partially collapsed voids filled with spar in the worm and algal layer of a laminoid stromatolite, locality P13; bar is $2 \mathrm{~mm}$; photomicrograph, cross-polarized light, KUMIP no. 214,920_— 3. Mottled stromatolite, locality P3, showing predominance of mud; slab, KUMIP no. 214,794.—4. Spar-filled void (possibly a burrow) through Spirorbis, encrusting foraminifera, and algae from a mottled stromatolite, locality P3; bar is $2 \mathrm{~mm}$; photomicrograph, KUMIP no. 214,921.-5. Podlike stromatolite with laminar fenestrae, locality P11; slab, KUMIP 214,830._— 6. Open fenestrae lined with equant spar, locality P1 1; bar is $4 \mathrm{~mm}$; photomicrograph, cross-polarized light, KUMIP no. 214,927.

upward, suggesting that the mat was pushed up and separated from the rest of the deposit (Fig. 7,6).

Mottled stromatolites.-Mottled stromatolites contain more mud, have a more diverse fauna with large whole gastropods, and have been more intensely bioturbated than any of the previously discussed types (Fig. 6). These stromatolites are exposed at localities near the western edge of the study area, which Fisher (1980) regarded as an open-marine environment (Fig. 10). The abundant mud is gray green and very fine grained except for millimeter-sized forami- 


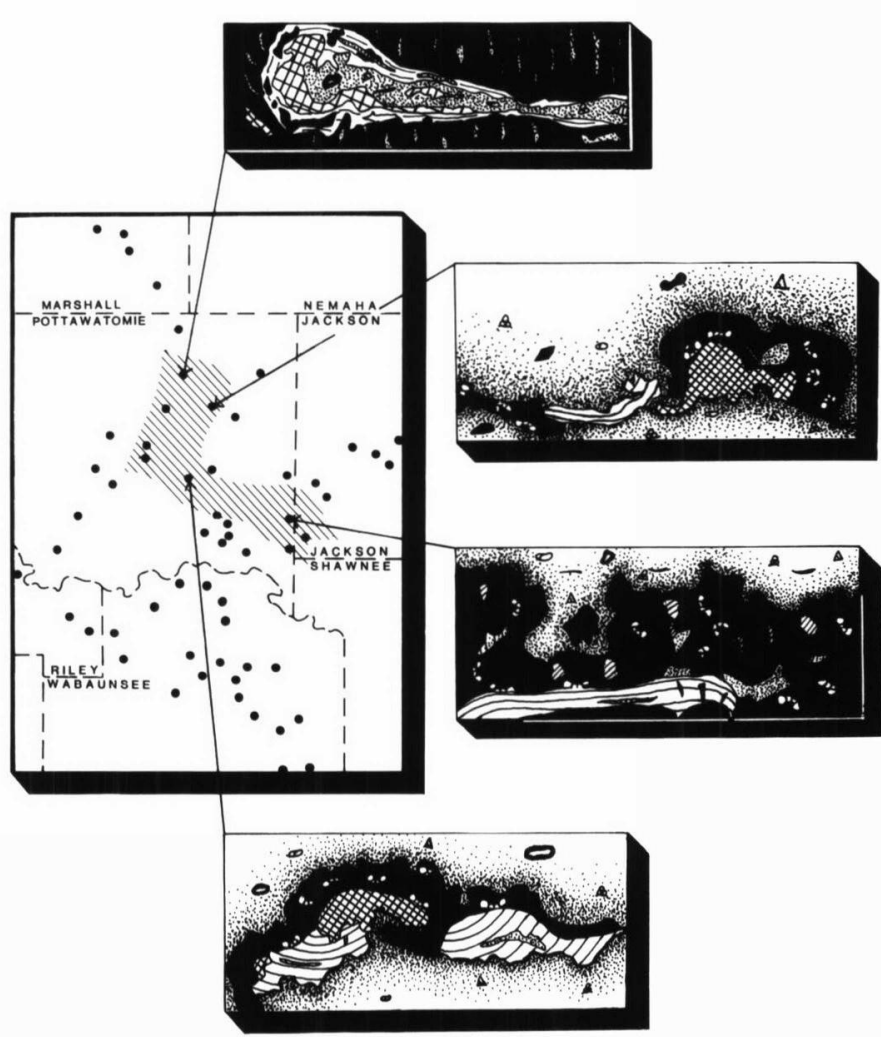

Fig. 9. Localities sampled, extent of the lagoon (cross-hatched pattern), and drawings of four, typical, pustular or laminoid stromatolites, $\times 0.4$. See Figure 4 for explanation of symbols.

nifera and shell fragments scattered throughout (Fig. 8,3). Encrusting foraminifera and abundant Spirorbis border sparfilled voids (Fig. 8,4). Larger voids are up to $4 \mathrm{~cm}$ across and are filled with spar and micritized algal bundles. Unlike the pustular structures, voids in mottled stromatolites are well preserved. Overlying these stromatolites are packstones of various compositions with grains that include whole gastropod shells about $5 \mathrm{~mm}$ across and large fragments of bivalve shells that are commonly coated with algae and encrusting foraminifera.

To generalize about these mottled stromatolites is difficult because outcrops are few. Nevertheless, samples indicate deposition in the least restricted, most open-marine or perhaps stable, lagoonal environment. The gray-green color and extensive bioturbation indicate quiet-water deposition and normal-marine salinity. The mottled nature of the deposits may have resulted from relatively continuous sedimentation or bioturbation, unlike that of peritidal environments (Monty, 1976). Although rounded outlines of many peloids suggest that they are fecal pellets, the abundance of preserved algal tubules in peloids of the muddier zones indicates, instead, in situ production from micritization of algal bundles as was also seen in the pustular and laminoid stromatolites (see Monty, 1976; Coniglio and James, 1984). Peloids that are clearly detrital are also present, but they are quite rare. Spar-filled voids in rocks rich in encrusting foraminifera and worm tubes are probably the result of burrowing (Fig. 8,4).

Pod-shaped stromatolites.-Pod-shaped stromatolites were collected from the tidal-flat lithofacies that Fisher (1980) recognized in the northeastern part of the study area. They are represented by only a few samples (Fig. 11). The small number of samples is due to the lack of limestone in much of the lower Americus in the area occupied by this facies. Outcrops are typically dominated by shale except for flat and domal, podlike, carbonate deposits (Fig. 6). These deposits usually lie at the same horizon and are less than $15 \mathrm{~cm}$ in diameter and $3 \mathrm{~cm}$ thick (Fig. 8,5). Samples from locality P11 (Fig. 1) are laminoid and domal and consist largely of limonitic mud, silt, and scattered peloids. No alga-rich layers or preserved algal tubules were observed. The rock is characterized by horizontal and vertical fenestrae up to $2 \mathrm{~cm}$ long that are lined with clear, equant spar; but the fenestrae are otherwise open (Fig. $8,6)$. Samples from locality J11, on the other hand, are nearly flat, as much as $6 \mathrm{~cm}$ across, and less than $1 \mathrm{~cm}$ thick. Edges of the pods are usually thicker and curled downward, with shallow desiccation cracks developed. They are dominated by carbonate mud and have no internal lamination or fenestrae. They contain a few Spirorbis tubes and fragments of other fossils.

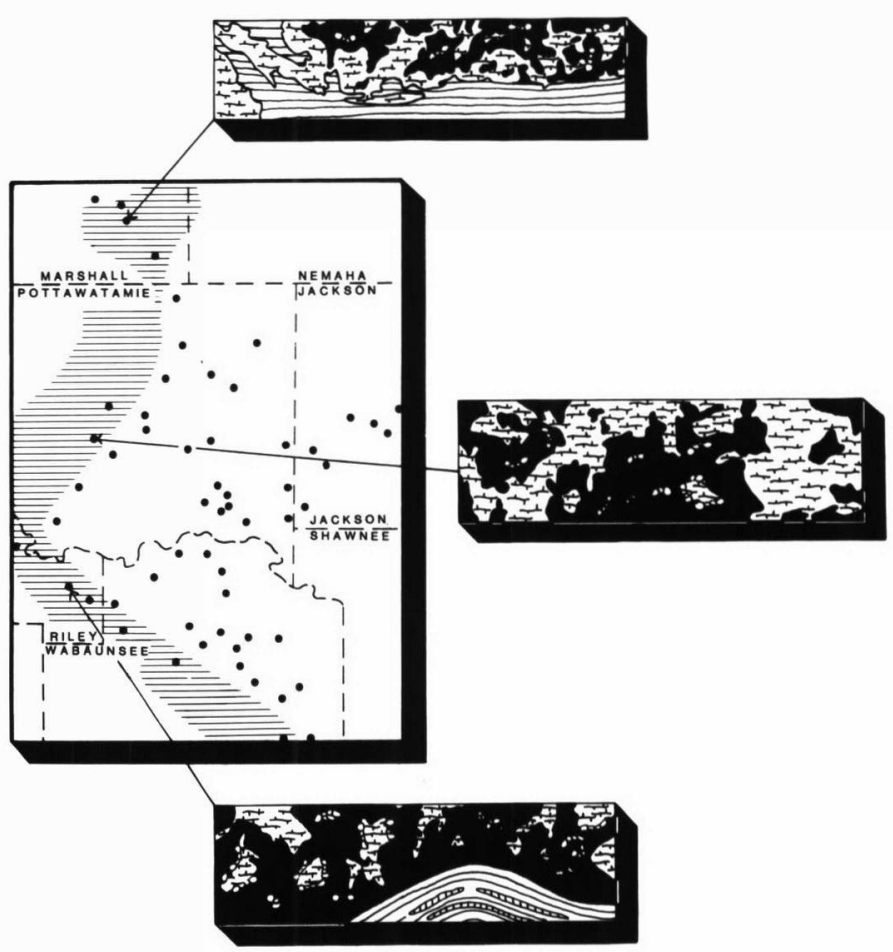

Fig. 10. Localities sampled, position of the open shelf (horizontal-line pattern), and drawings of three, typical, mottled stromatolites, $\times 0.4$. See Figure 4 for explanation of symbols. 


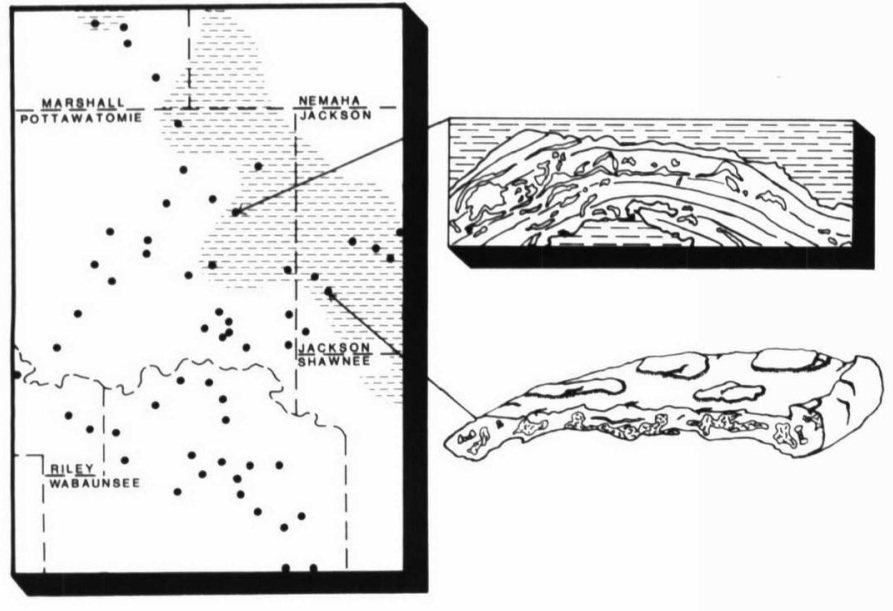

Fig. 11. Localities sampled, extent of the tidal flat (horizontal, hatched pattern), and drawings of two, typical, podlike stromatolites, $\times 0.4$. See Figure 4 for explanation of symbols.

Deposits at locality P11 are typical of supratidal or upper intertidal structures. Large, spar-lined fenestrae and limonitic stain strongly suggest extensive subaerial exposure. Thin deposits at locality J11 probably developed near the margins of the lagoon but were frequently exposed and thus poorly developed. The fact that both of these localities have scattered and podlike carbonate deposits surrounded by shale suggests that desiccation polygons developed, most of which were eroded away. The thicker, curled edges of the samples from locality J11 are typical of recent mats that have algae growing in water-soaked desiccation cracks but not in the middle of the polygons (Horodyski et al., 1977).

\section{SUMMARY AND CONCLUSIONS}

Morphology of stromatolites from the lower part of the Americus Limestone Member in northeastern Kansas is controlled in part by depositional environment. Smooth stromatolites formed in a relatively high-energy environment that was periodically subaerially exposed. Stromatolites with this morphology are confined roughly to the

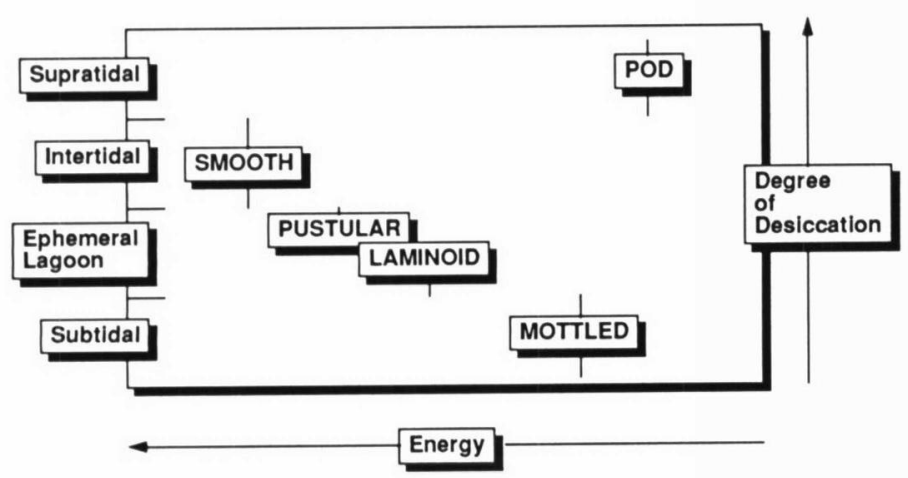

Fig. 12. Environmental-process grid for low-relief stromatolites of the Midcontinent. carbonate shoal and represent the earliest development of the shoal. Initial deposition was on a slightly raised substrate that was inundated, probably when the wind was strong, and exposed during periods of calm. The laminoid and pustular structures formed in an ephemeral lagoon behind the protective barrier of the carbonate shoal, which persisted until a broad shoal and lagoon had developed. Migration of the shoreline of the lagoon produced a tidal flat on which podlike stromatolites formed. The subtidal setting to the west and south of the shoal generated the mottled stromatolites along the low-energy, open coastline (see also Sporleder, 1987, 1991; Kaesler et al., 1990).

An environmental process grid (Fig. 12) that relates morphology of these stromatolites to both frequency of exposure and energy level can be used to interpret similar deposits, especially in Midcontinent rocks of late Paleozoic age. Although the grid of Figure 12 may need modification with further application, the following conclusions can be drawn.

(1) Low-relief stromatolites convey appreciable information about specific paleoenvironments beyond the fact that they were deposited in shallow, low-energy environments.

(2) Environmental processes rather than species of cyanobacteria present are judged to have most determined morphology in low-relief, late Paleozoic deposits. This conclusion is based on the similarity of these stromatolites to modern, presumably taxonomically different structures.

(3) Other cyclothems contain quite similar types of lowrelief stromatolites. Environmental-process grids should be useful in obtaining detailed and specific information about paleoenvironments in the Midcontinent, especially where other relationships are not readily available for study, as in cores from the subsurface.

Acknowledgments.-We wish to thank R. A. Robison, Paul Enos, D. F. Toomey, and two anonymous reviewers to whom we are grateful for suggestions that helped improve our manuscript. We also thank A. W. Walton and A. J. Rowell, with whom we discussed early phases of the research. Research funds were received from the Wallace E. Pratt Fund of Exxon Corporation, administered by the Department of Geology of The University of Kansas. The Department of Geology supported field work. Thin sections and slabs from which data were collected have been reposited in The University of Kansas Museum of Invertebrate Paleontology and assigned the numbers 214,782 to 214,969 .

\section{REFERENCES}

Coniglio, M., and N. P. James. 1984. Algal origin of peloids, peloidal intraclasts, and structure grumeleuse in Paleozoic limestones: evidence from Cow Head Group, western Newfoundland (abstract). American Assocociation of Petroleum Geologists Bulletin 68:464-465.

Davies, G. R. 1970. Algal-laminated sediments, Gladstone Embayment, Shark Bay, Western Australia. American Associa- 
tion of Petroleum Geologists Memoir 13:165-209.

Dunham, R. J. 1962. Classification of carbonate rocks according to depositional texture, p. 108-121. In W. E. Ham, ed., Classification of Carbonate Rocks. American Association of Petroleum Geologists Memoir 1.

Elias, M. K. 1937. Depth of deposition of the Big Blue (late Paleozoic) sediments in Kansas. Geological Society of America Bulletin 48:403-432.

1962. Comments on recent paleoecological studies of late Paleozoic rocks in Kansas, p. 106-115. In Kansas Geological Society 27th Field Conference Guidebook. Wichita, Kansas.

- 1964. Depth of late Paleozoic seas in Kansas and its megacyclic sedimentation. Kansas Geological Survey Bulletin 169:87-106.

Fisher, W. L. 1980. Variation in stratigraphy and petrology of the uppermost Hamlin Shale and Americus Limestone related to the Nemaha structural trend in northeastern Kansas. Unpublished Ph.D. dissertation. The University of Kansas. Lawrence, Kansas. 166 p.

Garber, M. S. 1962. Stratigraphy of the Foraker Limestone in east-central Kansas. Unpublished M.S. thesis. The University of Kansas. Lawrence, Kansas. 109 p.

Gebelein, C. D. 1969. Distribution, morphology, and accretion rate of recent subtidal algal stromatolites, Bermuda. Journal of Sedimentary Petrology 39:49-69.

1976. The effects of the physical, chemical, and biological evolution of the earth, p. 499-515. In M. R. Walter, ed., Stromatolites. Elsevier. New York.

Gerdes, G., W. E. Krumbein, and H.-E. Reineck. 1985. The depositional record of sandy, versicolored tidal flats (Mellum Island, southern North Sea). Journal of Sedimentary Petrology $55: 265-278$.

Ginsburg, R. N. 1955. Recent stromatolite sediments from south Florida. Journal of Paleontology 29:723-724.

Ginsburg, R. N., L. B. Isham, S. J. Bein, and J. Kuperberg. 1954. Laminated algal sediments of south Florida and their recognition in the fossil record. Unpublished report 54-20. Marine Laboratory, University of Miami. Coral Gables, Florida. 33 p.

Harbaugh, J, W., and F. Demirmen. 1964. Application of factor analysis to petrologic variations of Americus Limestone (Lower Permian), Kansas and Oklahoma. Kansas Geological Survey Special Distribution Publication 15. 40 p.

Hardie, L. A., and R. N. Ginsburg. 1977. Layering: the origin and environmental significance of lamination and thin bedding, p. 50-124. In Sedimentation of the Modern Carbonate Tidal Flats of Northwest Andros Island, Bahamas. Johns Hopkins University Studies in Geology. Baltimore.

Hoffman, P. F. 1976. Stromatolite morphogenesis in Shark Bay, Western Australia, p. 261-271. In M. R. Walter, ed., Stromatolites. Elsevier. New York.

Horodyski, R. J., B. Bloeser, and S. Vonder Haar. 1977. Laminated algal mats from a coastal lagoon, Laguna Mormona, Baja California, Mexico. Journal of Sedimentary Petrology 47:680-696.

Imbrie, John, L. F. Laporte, and D. F. Merriam. 1964. Beattie Limestone facies (Lower Permian) of the northern Midcontinent. Kansas Geological Survey Bulletin 169:219- 238.

Kaesler, R. L., J. C. Sporleder, and J. A. Pilch. 1990. Biofacies of Early Permian Ostracoda: response to subtle environmental change, p. 465-473. In R. C. Whatley and C. Maybury, eds.,
Ostracoda Global Bioevents in Earth History. Van NostrandReinhold. New York.

Logan, B. W. 1961. Cryptozoon and associated stromatolites from the recent of Shark Bay, Western Australia. Journal of Geology 69:517-533.

1974. Inventory of diagenesis in Holocene-recent carbonate sediments, Shark Bay, Western Australia. American Association of Petroleum Geologists Memoir 22:195-240.

Logan, B. W., Richard Rezak, and R. N. Ginsburg. 1964. Classification and environmental significance of algal stromatolites. Journal of Geology 72:68-83.

Logan, B. W., P. F. Hoffman, and C. D. Gebelein. 1974. Algal mats, cryptalgal fabrics and structures, Hamelin Pool, Western Australia. American Association of Petroleum Geologists Memoir 22:140-194.

McCrone, A. W. 1963. Paleoecology and biostratigraphy of the Red Eagle cyclothem (Lower Permian) in Kansas. Kansas Geological Survey Bulletin 164. 114 p.

-1964. Water depth and Midcontinent cyclothems. Kansas Geological Survey Bulletin 169:275-281.

Monty, C. L. V. 1967. Distribution and structure of recent stromatolitic algal mats, eastern Andros Island, Bahamas. Annales Societe Geologique de Belgique 90:55-100.

1976. The origin and development of cryptalgal fabrics, p. 193-249. In M. R. Walter, ed., Stromatolites. Elsevier. New York.

Moore, R. C. 1959. Geological understanding of cyclic sedimentation represented by Pennsylvanian and Permian rocks of northern Midcontinent region, p. 27-36. In Kansas Geological Society 24 th Field Conference Guidebook. Wichita, Kansas.

1964. Paleoecological aspects of Kansas Pennsylvanian and Permian cyclothems. Kansas Geological Survey Bulletin 169:287-380.

Mudge, M. R., and E. L. Yochelson. 1962. Stratigraphy and paleontology of the uppermost Pennsylvanian and lowermost Permian rocks in Kansas. United States Geologial Survey Professional Paper 323. 213 p.

Park, R. 1976. A note on the significance of lamination in stromatolites. Sedimentology 23:379-393.

Peterson, R. M., and R. L. Kaesler. 1980. Distribution and diversity of ostracode assemblages from the Hamlin Shale and the Americus Limestone (Permian, Wolfcampian) in northeastern Kansas. The University of Kansas Paleontological Contributions, Paper 100. 26 p.

Playford, P. E., and A. E. Cockbain. 1976. Modern algal stromatolites at Hamelin Pool, a hypersaline barred basin in Shark Bay, Western Australia, p. 389-411. In M. R. Walter, ed., Stromatolites. Elsevier. New York.

Pratt, B. R. 1982. Stromatolitic framework of carbonate mudmounds. Journal of Sedimentary Petrology 52:1203-1227.

Shinn, E. A., R. M. Lloyd, and R. N. Ginsburg. 1969. Anatomy of a modern carbonate tidal flat, Andros Island, Bahamas. Journal of Sedimentary Petrology 39:1202-1228.

Sporleder, J. C. 1987. Structural control of the distribution of subtidal to supratidal paleoenvironments of the Americus Limestone. Unpublished M.S. thesis. The University of Kansas. Lawrence, Kansas. 112 p.

1991. Structural control of the distribution of subtidal to supratidal paleoenvirnoments of the Americus Limestone Member (lowermost bed) in eastern Kansas. Kansas Geologi- 
cal Survey, Subsurface Geology Series 13. 58 p., 43 text-fig. Toomey, D. F., and J. A. Babcock. 1983. Precambrian and Paleozoic algal carbonates, west Texas-southern New Mexico. Colo- rado School of Mines Professional Contribution 11:1-345. Zeller, D. N., ed. 1968. The stratigraphic succession in Kansas. Kansas Geological Survey Bulletin 189. 81 p. 